\title{
PENGARUH KOMITMEN ORGANISASIONAL DAN DISIPLIN KERJA TERHADAP KINERJA KARYAWAN MELALUI KEPUASAN KERJA SEBAGAI VARIABEL INTERVENING
}

\author{
M. Aditya Putra Pratama ${ }^{1}$, Fareshti Nurdiana Dihan² \\ ${ }^{1}$ Universitas Islam Indonesia Yogyakarta \\ abrorjmi@gmail.com \\ ${ }^{2}$ Universitas Islam Indonesia \\ fereshtideevadha@gmail.com
}

\begin{abstract}
Organizational commitment, work discipline and job satisfaction to be part of the factors that influence performance. The purpose of this study was to determine the effect of organizational commitment and discipline on performance through job satisfaction as an intervening variable partially and simultaneously. This study also aimed to determine the effect of organizational commitment and discipline on performance through job satisfaction as an intervening variable directly and indirectly. This study was conducted to 150 respondents employees of PT. Arief Nirwana Utama. The research method used is quantitative method uses statistical and descriptive analysis.

The results of this study are (1) there is a significant effect of organizational commitment on employee job satisfaction. (2) there is a significant impact on job satisfaction labor discipline employees. (3) there is a significant effect of organizational commitment and discipline of work simultaneously on employee job satisfaction. (4) there is a significant effect of organizational commitment on performance. (5) there is a significant influence on the performance of employees work discipline. (6) significant influence of organizational commitment and discipline of work simultaneously on employee performance. (6) significant influence of organizational commitment and discipline of work simultaneously on employee performance. (7) significant influence of job satisfaction on employee performance. (8) there is a significant indirect effect of organizational commitment on performance through employee satisfaction. (9) there is a significant indirect effect on the performance of work discipline through employee satisfaction.
\end{abstract}

Keywords : Organizational Commitmen, Work Dicipline, Job Satisfaction, Performance.

(C) 2017 JBTI. All rights reserved

Article history : received 31 Jul 2017; revised 2 Ags 2017 ; accepted 12 Sep 2017

\section{PENDAHULUAN}

Tenaga kerja sebagai sumber daya yang sangat penting di dalam suatu organisasi. Organisasi akan lebih maju dan berkembang apabila mempunyai tenaga kerja yang handal, dan mampu dijadikan partner kerja oleh pimpinannya dalam menjalankan tugas yang menjadi bagiannya masing-masing. Tenaga kerja dan pimpinan harus saling mendukung, bekerjasama, saling menghargai, juga saling mengerti apa yang menjadi hak dan kewajibannya masing-masing. Perusahaan menggunakan berbagai macam cara untuk mencapai kinerja yang tinggi karena pada dasarnya manusia sebagai faktor yang penting dibanding faktor-faktor lainnya. 
Komitmen mempunyai peran penting dalam meningkatkan kinerja karyawan dalam sebuah organisasi. Tingginya komitmen akan berimbas pada kinerja karyawan yang semakin meningkat. Pernyataan ini didukung oleh Khan, et.al (dalam Taurisa dan Ratnawati, 2012) yang mengatakan komitmen dari seorang karyawan terhadap organisasinya dapat menjadi instrumen penting untuk meningkatkan kinerja dari karyawan tersebut. Hal ini diperkuat oleh pernyataan Smith (dalam Ciptodiharjo, 2013) bahwa komitmen organisasi berhubungan signifikan positif yang terhadap kinerja pegawai produksi.

Disiplin kerja juga merupakan salah satu faktor yang dapat meningkatkan kinerja karyawan. Hasibuan (dalam Ardansyah, 2014) menyatakan bahwa kedisiplinan kerja diartikan bilamana karyawan selalu datang dan pulang tepat waktu, mengerjakan semua pekerjaan dengan baik, mematuhi semua peraturan perusahaan dan norma-norma sosial yang berlaku. Hal ini diperkuat oleh hasil penelitian Hidayati (2014) menunjukkan bahwa disiplin kerja berpengaruh positif dan signifikan terhadap kinerja karyawan.

Komitmen organisasional mempunyai peran peting dalam meningkatkan kepuasan kerja. Badjuri (dalam Arifah dan Romadhon 2015) menyatakan bahwa komitmen organisasional mempengaruhi berbagai perilaku penting agar organisasi dapat tumbuh mana kala harapan kerja terpenuhi oleh organisasi dengan baik. Selanjutnya dengan terpenuhinya harapan kerja ini akan menimbulkan kepuasan kerja. Hubungan dari kepuasan kerja dengan turnover interntion dan komitmen organisasi lebih dipengaruhi oleh kepuasan kerja sebagai antecedent dari komitmen organisasional (Lin and Ma, 2004; Tett and Meyer, 1993; dalam Iqbal et al 2014).

Disiplin kerja pun memiliki keterkaitan dengan kepuasan kerja. Susilo (dalam Agusta dan Supartha, 2013) mengungkapkan bahwa terdapat beberapa faktor yang mempengaruhi kepuasan kerja karyawan, yaitu kepemimpinan, hubungan kerja, dan disiplin kerja Hal ini diperkuat oleh penelitian Arina (2015) yang menyatakan disiplin kerja berpengaruh signifikan terhadap kepuasan kerja karyawan pada CV. Yamaha Siteba Padang.

Keberhasilan organisasi dipengaruhi oleh adanya tingkat kepuasan yang dirasakan karyawan. Kepuasan yang dirasakan setiap karyawan akan mengakibatkan peningkatan dalam kinerja seorang karyawan, karena menganggap pekerjaannya sebagai sebagai suatu yang menyenangkan. Pernyataan ini didukung oleh Robbins (dalam Indrawati, 2013) yang menyatakan bahwa karyawan yang puas berkemungkinan lebih besar untuk berbicara secara positif tentang organisasi, membantu yang lain, dan kinerja pekerjaan mereka melampaui perkiraan normal. Hal ini didukung oleh Taurisa dan Ratnawati (2012) bahwa terdapat pengaruh yang searah antara komitmen organisasional dan kinerja karyawan. Hal ini menunjukkan bahwa semakin tinggi komitmen organisasional dalam diri karyawan PT. Sido Muncul, maka semakin tinggi tingkat kinerja karyawannya.

Kinerja karyawan yang baik akan memberikan keuntungan untuk jangka panjang terhadap perusahaan, maka dari itu karyawan harus dapat mengelola dengan cara yang tepat. Windryanto (dalam Utomo, 2011) menyatakan bahwa kinerja karyawan merupakan hasil kerja yang dicapai oleh seseorang karyawan dalam menjalankan tugas kewajibannya sebagai seorang pegawai/karyawan, dengan demikian persoalan kinerja karyawan juga berhubungan dengan persoalan kemampuan orang untuk mengembangkan dirinya agar mampu berkarya mencapai tujuan yang dikehendaki oleh organisasi.

Dari beberapa paparan diatas maka peneliti tertarik untuk mengambil judul "Pengaruh Komitmen Organisasional dan Disiplin Kerja terhadap Kinerja Karyawan melalui Kepuasan Kerja sebagai Variabel Interverning pada PT. Arief Nirwana Utama di kota Rantau, Tapin, Kalimantan Selatan". PT. Arief Nirwana Utama merupakan perusahaan yang bergerak di bidang industri minyak mentah yang memproduksi kelapa sawit dalam bentuk tandan buah segar dan kedepannya akan memproduksi minyak mentah. 


\section{KAJIAN TEORI}

\section{A. Komitmen Organisasional}

Komitmen organisasional merupakan suatu sikap yang merefleksikan perasaan suka atau tidak suka dari karyawan terhadap organisasi. Komitmen karyawan pada organisasi sebagai ikatan kejiwaan individu terhadap organisasi yang mencangkup keterlibatan kerja, kesetiaan, dan perasaan percaya terhadap nilai-nilai organisasi. Bentuk komitmen yang muncul bukan hanya bersifat loyalitas yang pasif tetapi harus memberikan segala usaha demi keberhasilan organisasi yang bersangkutan (Robbins; O'Reilly; Steers dan Porter; dalam Sopiah, 2008). Gibson (dalam Nelly, 2013) berpendapat bahwa komitmen adalah keterlibatan seorang karyawan yang menunjukkan adanya rasa pengidentifikasian dengan tujuan perusahaan, perasaan keterlibatan dalam perusahaan, dan rasa kesetiaan.

Menurut Newstroom; Hunt dan Morgan; Steers dan Black (dalam Sopiah, 2008) komitmen organisasional ditandai oleh tiga hal, yaitu rasa percaya yang kuat dan penerimaan seorang terhadap tujuan dan nilai-nilai organisasi, keinginan seseorang untuk melakukan usaha secara sungguhsungguh demi organisasi, dan hasrat yang kuat untuk mempertahankan keanggotaan dalam suatu organisasi.

Mayer et al. (dalam Sopiah, 2008) mengemukanan bahwa ada tiga komponen komitmen organisasional, yaitu: 1). Affective commitment, terjadi apabila karyawan ingin menjadi bagian dari organisasi karena adanya ikatan emosional. 2). Continuance commitment muncul, apabila karyawan tetap bertahan pada suatu organisasi karena membutuhkan gaji, dan keuntungan-keuntungan lain, atau karena karyawan tersebut tidak menemukan pekerjaan lain. Dan 3). Normative commitment, timbul dari nilai dalam diri karyawan. Karyawan bertahan menjadi anggota organisasi karena adanya kesadaran bahwa komitmen terhadap organisasi merupakan hal yang seharusnya dilakukan.

\section{B. Disiplin Kerja}

Hasibuan (2006) dan Singodimejo (dalam Sutrisno, 2010) menyatakan bahwa disiplin kerja adalah kesadaran dan kerelaan seseorang dalam menaati semua peraturan perusahaan dan normanorma sosial yang berlaku. Sedangkan menurut Rivai (2011) bahwa disiplin kerja merupakan suatu alat yang dipergunakan para manajer untuk berkomunikasi dengan karyawan agar mereka bersedia untuk mengubah suatu perilaku, serta sebagai suatu upaya untuk meningkatkan kesadaran dan kesedian seorang dalam memenuhi segala peraturan perusahaan.

Menurut Singodimedjo (dalam Sutrisno, 2010) factor-faktor yang mempengaruhi kedisiplinan karyawan adalah :

1. Besar kecilnya pemberian kompensasi

Para karyawan akan mematuhi segala peraturan yang berlaku, bila ia merasa mendapat jaminan balas jasa yang setimpal dengan jerih payahnya yang telah dikontribusikannya bagi perusahaan.

2. Ada tidaknya keteladanan pimpinan dalam perusahaan.

Semua karyawan akan selalu memperhatikan bagaimana pimpinan dalam menegakkan kedisiplinan dirinya, dan bagaimana ia dapat mengendalikan dirinya sendiri seperti ucapan, perbuatan, dan sikap yang dapat merugikan aturan kedisiplinan yang sudah ditetapkan.

3. Ada tidaknya aturan pasti yang dapat dijadikan pegangan.

Pembinaan disiplin tidak akan dapat terlaksana dalam perusahaan, bila tidak ada aturan tertulis yang pasti untuk dapat dijadikan pegangan bersama. 
4. Keberanian pimpinan dalam mengambil tindakan.

Bila ada seseorang karyawan yang melanggar kedisiplinan, maka perlu ada keberanian pimpinan untuk mengambil tindakan yang sesuai dengan pelanggarannya.

5. Ada tidaknya pengawasan pimpinan.7

Dalam setiap kegiatan yang dilakukan oleh perusahaan perlu ada pengawasan, yang akan mengarahkan para karyawan agar dapat melaksanakan pekerjaan dengan tepat dan sesuai dengan yang telah ditetapkan.

6. Ada tidaknya perhatian kepada karyawan.

7. Diciptakan kebiasaan-kebiasaan yang mendukung tegaknya kedisiplinan.

Menurut Mangkunegara (2011) terdapat 3 bentuk disiplin kerja, yaitu: 1). Disiplin preventif, yang merupakan suatu upaya untuk menggerakan karyawan agar mau mengikuti dan mematuhi pedoman kerja dan aturan aturan yang telah digariskan oleh perusahaan. 2). Disiplin korektif, yang merupakan suatu upaya untuk menggerakan pegawai dalam suatu peraturan dan mengarahkan untuk tetap mematuhi peraturan sesuai dengan pedoman yang berlaku pada perusahaan. Dan 3). Disiplin progresif, yaitu merupakan kegiatan yang memberikan hukuman-hukuman yang lebih berat terhadap pelanggaran-pelanggaran yang berulang.

\section{Kepuasan Kerja}

Menurut pendapat Robbins (2002:91) istilah kepuasan kerja merujuk kepada sikap umum seorang individu terhadap pekerjaan yang dilakukannya. Seseorang dengan tingkat kepuasan kerja tinggi menunjukan sikap yang positif terhadap kerja itu, sedangkan seseorang yang tidak puas dengan pekerjaannya menunjukan sikap yang negatif terhadap pekerjaan itu.

Smith (dalam Robbins, 2002) menyatakan terdapat 5 dimensi yang mempengaruhi respon afektif seseorang terhadap pekerjaannya, yaitu 1). Pekerjaan itu sendiri, yaitu sejauh mana pekerjaan menyediakan kesempatan seseorang untuk belajar memperoleh tanggung jawab dalam suatu tugas tertentu dan tantangan untuk pekerjaan yang menarik. 2). Bayaran, yaitu upah yang diperoleh seseorang sebanding dengan usaha yang dilakukan dan sama dengan upah yang diterima oleh orang lain dalam posisi kerja yang sama. 3). Kesempatan untuk promosi, yaitu kesempatan seseorang untuk meraih atau dipromosikan ke jenjang yang lebih tinggi dalam organisasi. 4). Atasan, yaitu kemampuan atasan untuk memberikan bantuan tehnis dan dukungan terhadap pekerjaan yang menjadi tanggung jawab para bawahan. 5). Rekan kerja, yaitu sejauh mana rekan kerja secara tehnis cakap dan secara social mendukung tugas rekan kerja lainnya.

\section{Kinerja}

Bernardin dan Russel (2003) memberikan pengertian kinerja sebagai berikut : "performance is defined as the record of outcomes produced on a specified job function or activity during time period". Prestasi atau kinerja adalah catatan tentang hasil-hasil yang diperoleh dari fungsi-fungsi pekerjaan tertentu atau kegiatan selama kurun waktu tertentu.

Untuk mengukur kinerja karyawan, dapat digunakan beberapa dimensi mengenai kriteria kinerja yang menurut Bernardin \& Russel (2003: 135) adalah sebagai berikut: 1). Kualitas (Quality), yaitu merupakan tingkatan dimana proses atau hasil dari penyelesaian suatu kegiatan mendekati sempurna. 2). Kuantitas (Quantity), yaitu merupakan produksi yang dihasilkan dapat ditunjukkan dalam satuan mata uang, jumlah unit, atau jumlah siklus kegiatan yang diselesaikan. 3). Ketepatan waktu (timelinnes), yaitu merupakan dimana kegiatan tersebut dapat diselesaikan, atau 
suatu hasil produksi dapat dicapai, pada permulaan waktu yang ditetapkan bersamaan koordinasi dengan hasil produk yang lain dan memaksimalkan waktu yang tersedia untuk kegiatan-kegiatan lain. 4). Efektivitas biaya (cost effectivennes), yaitu merupakan tingkatan dimana sumber daya organisasi, seperti manusia, keuangan, teknologi, bahan baku dapat dimaksimalkan dalam arti untuk memperoleh keuntungan yang paling tinggi atau mengurangi kerugian yang timbul dari setiap unit. 5). Kebutuhan akan pengawasan (need for supervision), yaitu merupakan tingkatan dimana seorang karyawan mampu melaksanakan suatu fungsi pekerjaan tanpa membutuhkan bantuan pengawasan atau memerlukan campur tangan pengawas untuk mencegah agar hasil produksi tidak mengalami kerugian. 6). Hubungan antar perseorangan (Interpersonal impact), yaitu merupakan tingkatan dimana seorang karyawan mampu untuk mengembangkan perasaan saling menghargai, niat baik, dan kerjasama antara karyawan yang satu dengan yang lain, dan juga pada bawahan.

\section{E. Tinjauan Penelitian Terdahulu}

Penelitian Chandra (2013) "Pengaruh Komitmen Organisasi dan Kepemimpinan terhadap Kepuasan Kerja dan Kinerja Karyawan PD. Wonoagung Sejahtera di Gresik”. Hasil penelitian ini menunjukan bahwa komitmen organisasi berpengaruh terhadap kepuasan kerja dan kinerja. Dan kepuasan kerja mempunyai pengaruh pula terhadap kinerja. Nydia (2012) dalam penelitian "Pengaruh Komitmen Organisasi Terhadap Kinerja Karyawan Lapangan SPBU COCO Pertamina MT Haryono" menunjukan bahwa komitmen organisasi yang terdiri dari komitmen afektif, berkelanjutan, dan normative berpengaruh secara simultan terhadap karyawan. Secara parsial komitmen afektif dan komitmen berkelanjutan, berpengaruh positif dan signifikan terhadap kinerja, sedangkan komitmen normative tidak berpengaruh signifikan terhadap kinerja karyawan. Komitmen berkelanjutan yang merupakan salah satu jenis variabel komitmen organisasi memiliki pengaruh dominan terhadap kinerja karyawan lapangan. Nanda (2014) dalam penelitian "Analisis Pengaruh Motivasi Kerja, Pengendalian Internal, dan Komitmen Organisasi terhadap Kinerja Karyawan" (Studi Empirin Pada AJB Bumi Putera 2912 Kantor Cabang Solo Gladag) mengemukakan hal yang senada, yaitu bahwa variabel komitmen organisasi berpengaruh positif terhadap kinerja karyawan. Penelitian lain yang menyampaikan hasil serupa juga dikemukakan oleh Utomo (2011) dalam penelitian "Pengaruh Motivasi Kerja, Kepuasan Kerja, dan Komitmen Organisasional terhadap Kinerja Pegawai” (Studi pada pegawai Setda Kabupaten Pati).

Agusta dan Supartha (2013) dalam penelitian "Pengaruh Kepemimpinan, Hubungan Kerja, dan Disiplin Kerja terhadap Kepuasan Kerja karyawan pada PT. Bintang Bali Indah Denpasar" menyatakan bahwa disiplin kerja berpengaruh positif dan signifikan terhadap kepuasan kerja. Hal sejalan disampaikan Sudiyanto (2015) dalam penelitian "Pengaruh Disiplin, Budaya Kerja, dan Motivasi terhadap Kepuasan Kerja pegawai pada Fakultas Ekonomi Universitas PGRI Palembang” yang menunjukan bahwa disiplin kerja berpengaruh secara positif dan signifikan terhadap kepuasan kerja. Arina (2015) dalam penelitiannya berjudul "Pengaruh Lingkungan Kerja dan Disiplin Kerja terhadap Kepuasan Kerja Karyawan pada CV. Yamaha Siteba Padang” menyampaikan bahwa disiplin kerja berpengaruh signifikan terhadap kepuasan kerja. Penelitian-penelitian lain yang mempunyai hasil serupa dikemukakan pula oleh Hidayati (2014) dalam penelitian "Analisis Pengaruh Motivasi dan Disiplin Kerja terhadap Kinerja Karyawan PT. Kemilau Indah Permana Kebakkramat Karanganyar"; Baihaqi (2013) dalam "Pengaruh Kepemimpinan dan Disiplin Kerja terhadap Kinerja Pegawai dengan Kepuasan Kerja sebagai Variabel Moderating” (Studi kasus pada Dinas Kehutanan Kabupaten Kutai Timur, Kalimantan Timur); Jayanti (2014) dalam "Analisis Pengaruh Motivasi Kerja, Kepuasan Kerja, Kontrak Psikologis, Disiplin Kerja dan Lingkungan Kerja terhadap Kinerja Karyawan RSUD Kota Semarang”; Ardansyah dan Wasilawati (2014) dalam penelitian "Pengawasan, Disiplin Kerja, dan Kinerja Pegawai Badan Pusat Statistik Kabupaten Lampung Tengah"; S. Timbuleng \& J.S.B. Sumarauw (2015) dalam penelitian "Etos Kerja, Disiplin Kerja dan Komitmen Organisasi Pengaruhnya terhadap Kinerja Karyawan Pada PT. Hasjrat Abadi Cabang Manado". 
Putri dan Latrini (2013) dalam penelitian "Pengaruh Kepuasan Kerja terhadap Kinerja Karyawan Sektor Publik, dengan In-role Performance dan Innovative Performance sebagai Variabel Mediasi" menunjukan bahwa kepuasan kerja berpengaruh positif terhadap kinerja. Senada dengan yang disampaikan oleh Ciptodihardjo (2013) dalam penelitian "Pengaruh Kepemimpinan, Motivasi, Kepuasan Kerja dan Komitmen Organisasional dan Kinerja Karyawan pada karyawan PT. Smartfren, Tbk di Surabaya" menyatakan bahwa kepuasan kerja bepengaruh terhadap kinerja karyawan. Umar (2011) dalam penelitian "Pengaruh Upah, Motivasi Kerja, dan Kepuasan Kerja terhadap Kinerja Pekerja pada Industri Manufaktur di Kota Makassar" menyatakan bahwa kepuasan kerja berpengaruh signifikan terhadap kinerja.

Mulyanto \& Mini S (2013) dalam penelitian "Pengaruh Komitmen Organisasi dan Disiplin Kerja terhadap Kepuasan Kerja dalam Upaya Meningkatkan Kinerja Pegawai RS. Ortopedi Prof. Dr. R. Soeharso Surakarta" menunjukkan bahwa ada pengaruh langsung komitmen organisasi terhadap kinerja dibandingkan pengaruh komitmen organisasi terhadap kinerja melalui kepuasan kerja.

\section{F. Hipotesis}

H1: Ada pengaruh yang signifikan komitmen organisasional terhadap kepuasan kerja karyawan

$\mathrm{H} 2$ : Ada pengaruh yang signifikan disiplin kerja terhadap kepuasan kerja karyawan

H3: Ada pengaruh yang signifikan komitmen organisasional dan disiplin kerja secara simultan terhadap kepuasan kerja karyawan

H4: Ada pengaruh yang signifikan komitmen organisasional terhadap kinerja

H5: Ada pengaruh yang signifikan disiplin kerja terhadap kinerja karyawan

H6: Ada pengaruh yang signifikan komitmen organisasional dan disiplin kerja secara simultan terhadap kinerja karyawan.

H7: Ada pengaruh yang signifikan kepuasan kerja terhadap kinerja karyawan

H8: Ada pengaruh tidak langsung yang signifikan komitmen organisasional terhadap kinerja melalui kepuasan kerja karyawan

H9: Ada pengaruh tidak langsung yang signifikan disiplin kerja terhadap kinerja melalui kepuasan kerja karyawan

\section{G. Kerangka Konseptual}

Penelitian ini terdiri dari variabel independent atau variabel bebas $(\mathrm{X})$ yaitu komitmen organisasional, dan disiplin kerja, variabel dependent atau variabel terikat (Y) yaitu kinerja, dan variabel intervening $(Z)$ yaitu kepuasan kerja. Untuk lebih jelasnya maka dapat dilihat dalam bentuk sebagai berikut :

Kerangka pemikiran dalam penelitian ini adalah sebagai berikut : 
$\mathrm{H} 4$

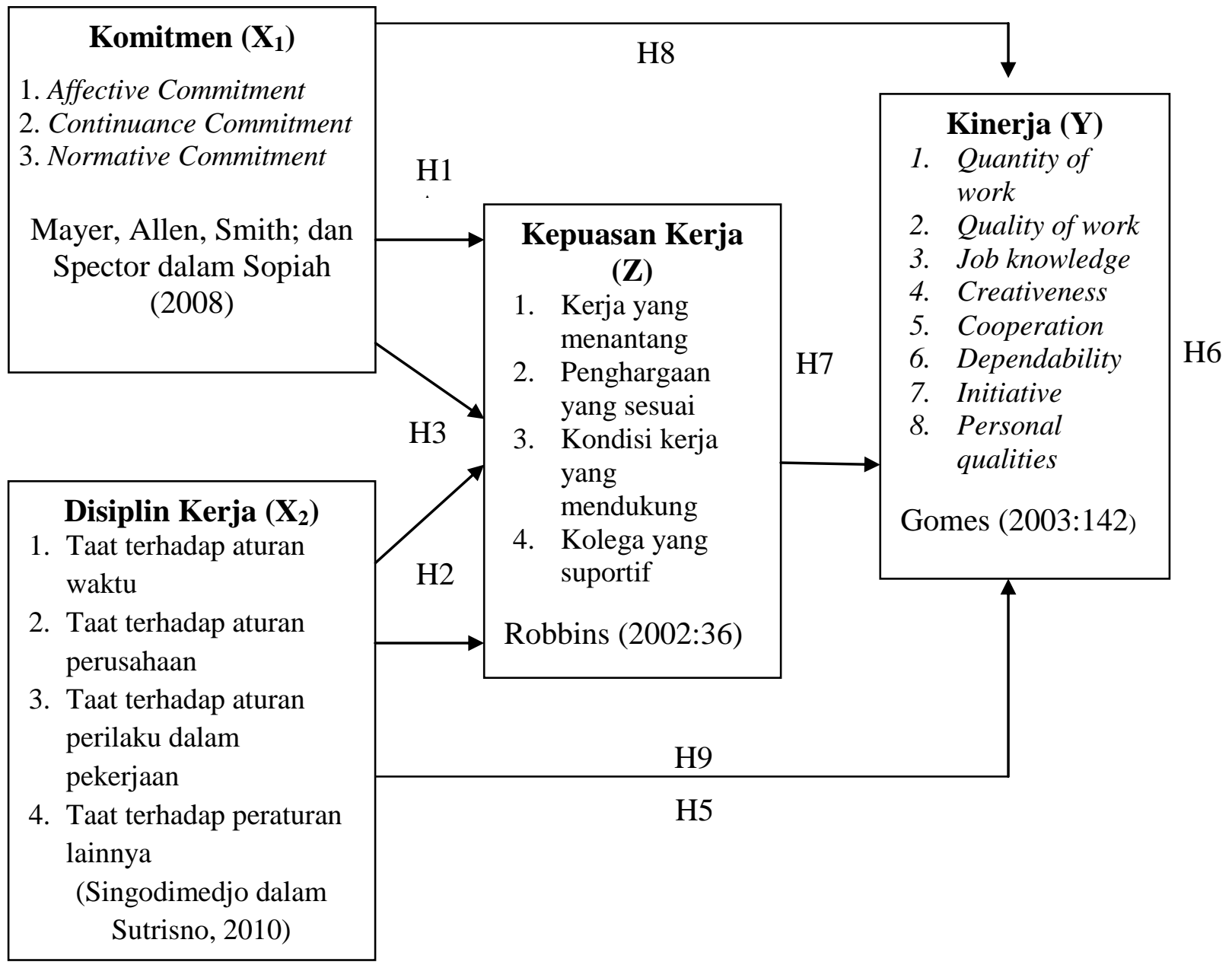

Gambar 1. Kerangka Penelitian

\section{METODE PENELITIAN}

\section{A. Lokasi Penelitian}

Penelitian ini dilakukan di Kabupaten Tapin Provinsi Kalimantan Selatan yang bergerak di bidang kelapa sawit PT. Arief Nirwana Utama yang berdiri pada tanggal 30 Januari 2009.

\section{B. Pendekatan Penelitian}

Penelitian ini menggunakan metode kuantitatif dengan meneliti data primer yang diperoleh dari perusahaan. Data primer adalah data asli yang dikumpulkan sendiri oleh penulis untuk menjawab masalah risetnya secara khusus (Istijanto, 2005:38). Pengumpulan data dilakukan dengan cara menyebar kuesioner yang dibagikan kepada karyawan menggunakan teknik survey. Responden diminta menjawab pertanyaan yang ada dalam kuesioner dengan menggunkan skala likert. 


\section{Definisi Operasional Variabel}

\section{Komitmen Organisasi $\left(\mathrm{X}_{1}\right)$}

Mayer, Smith, dan Spector (dalam Sopiah, 2008) mengemukanan bahwa ada tiga komponen komitmen organisasional, yaitu Affective commitment, Continuance commitment, dan Normative commitment. Komitmen afektif terjadi apabila karyawan ingin menjadi bagian dari organisasi karena adanya ikatan emosional. Komitmen berkelanjutan muncul apabila karyawan tetap bertahan pada suatu organisasi karena membutuhkan gaji, dan keuntungan-keuntungan lain, atau karena karyawan tersebut tidak menemukan pekerjaan lain. Komitmen normatif timbul dari nilai dalam diri karywan. Karyawan bertahan menjadi anggota organisasi karena adanya kesadaran bahwa komitmen terhadap organisasi merupakan hal yang seharusnya dilakukan.

\section{Disiplin Kerja $\left(\mathbf{X}_{2}\right)$}

Disiplin Kerja adalah kesadaran dan kesedian seseorang menaati semua peraturan perusahaan dan norma-norma sosial yang berlaku (Singodimedjo dalam Sutrisno, 2010). Dimensidimensi dari variabel ini adalah : taat terhadap aturan waktu, aturan perusahaan, aturan perilaku dalam pekerjaan, dan aturan-aturan lainnya.

\section{Kepuasan Kerja (Z)}

Menurut pendapat Robbins (2002:91) istilah kepuasan kerja merujuk kepada sikap umum seorang individu terhadap pekerjaan yang dilakukannya. Seseorang dengan tingkat kepuasan kerja tinggi menunjukan sikap yang positif terhadap kerja itu, sedangkan seseorang yang tidak puas dengan pekerjaannya menunjukan sikap yang negatif terhadap pekerjaan itu.

Indikator kepuasan kerja menurut Robbins (2002:36) antara lain: pekerjaan yang menantang, kompensasi yang layak, kondisi lingkungan kerja, hubungan dengan rekan kerja dan atasan.

\section{Kinerja (Y)}

Bernardin dan Russel (2003) memberikan pengertian kinerja sebagai catatan tentang hasilhasil yang diperoleh dari fungsi-fungsi pekerjaan tertentu atau kegiatan selama kurun waktu tertentu. Indikator menurut Gomes (2003:142) antara lain : jumlah kerja yang dilakukan dalam suatu periode waktu yang ditentukan (Quantity of work), kualitas kerja yang dicapai berdasarkan syarat-syarat kesesuaian dan kesiapannya (Quality of work), luasnya pengetahuan dan ketrampilan mengenai pekerjaan (Job knowledge), keaslian gagasan-gagasan yang dimunculkan dan tindakantindakan untuk menyelesaikan persoalan-persoalan yang timbul (Creativeness), kesediaan untuk bekerja sama dengan sesama anggota organisasi (Cooperation), kesadaran dan dapat dipercaya dalam hal kehadiran dan menyelesaikan pekerjaan (Dependability), semangat untuk menyelesaikan tugas-tugas baru dalam memperbesar tanggung jawabnya (Initiative), kepribadian dan keramahtamahan (Personal qualities).

\section{Jenis dan Teknik Pengumpulan Data}

Data yang dipakai adalah data primer, yaitu data yang diperoleh langsung oleh penulis dari objek riset (Sumarsono, 2004:69). Pengumpulan data dilakukan dengan cara menyebarkan kuesioner kepada responden. Kuesioner yang disebarkan berisi pertanyaan mengenai komitmen organisasi, disiplin kerja, kepuasan kerja, dan kinerja. Setiap poin jawaban pada kuesioner ditentukan skornya menggunakan skala Likert.

\section{E. Populasi dan Sampel}

Dalam penelitian ini populasinya adalah seluruh karyawan kontrak PT Arief Nirwana Utama yang berjumlah 150 orang. Mengingat jumlah populasi relatif sedikit, maka pengambilan sampel dalam penelitian ini menggunakan metode sensus. Dengan demikian jumlah subyek dalam penelitian ini sebanyak 150 orang. 


\section{F. Metode Analisis Data}

Terdapat dua metode analisis data yang digunakan dalam penelitian ini, yaitu berupa analisis deskriptif dan analisis statistik. Analisis statistik yang digunakan adalah analisis regresi linier berganda.

\section{HASIL DAN PEMBAHASAN}

\section{A. Hasil Uji Instrumen}

Uji instrumen dalam penelitian ini menggunakan uji validitas dan reliabilitas. Hasil uji validitas pada pertanyaan kuesioner hasilnya secara keseluruhan valid. Sedangkan hasil uji reliabilitas secara keseluruhan reliabel.

\section{B. Analisis Deskriptif}

Penelitian ini dilakukan pada 150 sampel yang berstatus karyawan dari PT. Arief Nirwana Utama. Demografi responden yang mendominasi penelitian ini adalah berjenis kelamin pria sebanyak 103 orang, dengan usia 21-30 tahun sebanyak 64 orang, dan pendidikan seluruh karyawan adalah tamatan SMA/SMK sebanyak 150 orang, serta masa kerja antara 6-10 tahun sebanyak 87 orang.

\section{Tabel 1.}

Deskriptif Variabel Kinerja Karyawan

\begin{tabular}{|c|c|c|c|}
\hline No. & Item & Rerata & Kategori \\
\hline 1. & Kemampuan bekerja dengan waktu yang ditentukan & 4,23 & sangat baik \\
\hline 2. & Kemampuan memenuhi jumlah barang sesuai permintaan & 4,25 & sangat baik \\
\hline 3. & Kecepatan menyelesaikan pekerjaan & 4,25 & sangat baik \\
\hline 4. & Pemenuhan syarat untuk bekerja & 4,32 & sangat baik \\
\hline 5. & Kemampuan menyelesaikan pekerjaan sesuai standar & 4,17 & baik \\
\hline 6. & Kecekatan dalam bekerja & 4,17 & baik \\
\hline 7. & Kemampuan menjaga mutu pekerjaan & 4,29 & sangat baik \\
\hline 8. & Kemampuan menjaga mutu produk & 4,23 & sangat baik \\
\hline 9. & Pengetahuan mengenai bidang pekerjaan dengan rinci & 4,14 & baik \\
\hline 10. & Pemahaman terhadap pekerjaan rutin yang diberikan & 4,22 & sangat baik \\
\hline 11. & Pemahaman terhadap pekerjaan rutin yang diberikan & 4,40 & sangat baik \\
\hline 12. & Penggunaan keterampilan khusus dalam bekerja & 4,23 & sangat baik \\
\hline 13. & Penggunaan wawasan yang luas dalam bekerja & 4,24 & sangat baik \\
\hline
\end{tabular}




\begin{tabular}{|c|c|c|c|}
\hline 14. & Kemampuan memberikan ide atau gagasan dalam forum/rapat & 4,25 & sangat baik \\
\hline 15. & Kemampuan menyelesaikan masalah yang muncul & 4,31 & sangat baik \\
\hline 16. & Kemampuan menciptakan situasi kerja yang berbeda & 4,16 & baik \\
\hline 17. & Kemauan bekerja sama dengan karyawan lain & 4,17 & baik \\
\hline 18. & Kemampuan bekerja sama dengan karyawan lain & 4,29 & sangat baik \\
\hline 19. & Kemampuan untuk mengimbangi keterampilan anggota lain & 4,22 & sangat baik \\
\hline 20. & Kemauan berbagi keterampilan dengan karyawan lain & 4,13 & baik \\
\hline 21. & Konstribusi tenaga dalam pekerjaan & 4,23 & sangat baik \\
\hline 22. & Kemampuan menyelesaikan pekerjaan rutin secara mandiri & 4,40 & sangat baik \\
\hline 23. & Kemampuan menyelesaikan pekerjaan tidak rutin secara mandiri & 4,24 & sangat baik \\
\hline 24. & Kesadaran dalam bekerja secara mandiri & 4,25 & sangat baik \\
\hline 25. & Semangat menyelesaikan pekerjaan rutin secara mandiri & 4,25 & sangat baik \\
\hline 26. & Semangat menyelesaikan pekerjaan tidak rutin secara mandiri & 4,32 & sangat baik \\
\hline 27. & Kemauan untuk bertanggungjawab & 4,17 & baik \\
\hline 28. & Kemampuan menjaga amanah (tugas) dari atasan & 4,17 & baik \\
\hline 29. & Kepekaan terhadap lingkungan sekitar & 4,29 & sangat baik \\
\hline 30. & Ketaatan dalam beribadah & 4,23 & sangat baik \\
\hline 31. & Sikap ramah terhadap rekan di lingkungan kerja & 4,15 & baik \\
\hline 32. & Sikap baik terhadap rekan di lingkungan kerja & 4,23 & sangat baik \\
\hline 33. & Sikap komunikatif terhadap rekan di lingkungan kerja & 4,40 & sangat baik \\
\hline \multicolumn{2}{|r|}{ Rata-rata variabel kinerja } & 4,24 & sangat baik \\
\hline
\end{tabular}

Berdasarkan hasil perhitungan secara deskriptif menunjukkan pada nomor 11,22, dan 33 merupakan item yang memiliki rerata paling tinggi yaitu sebesar 4,40. Artinya mayoritas dari 150 responden cenderung menjawab setuju pada pernyataan tersebut. Rata-rata secara umum dari variabel kinerja yaitu 4,24 yang juga masuk dalam kategori sangat baik. Hasil rata-rata pada variabel ini dapat diartikan bahwa kinerja karyawan baik dalam hal kuantititas, kualitas, pengetahuan atas pekerjaannya, kreatif, sikap saling bekerja sama, inisiatif, dan kualitas pribadi. 
Tabel 2.

Deskriptif Variabel Komitmen Organisasional

\begin{tabular}{|c|c|c|c|}
\hline No. & Item & Rerata & Kategori \\
\hline 1. & Merasa nyaman di dalam organisasi ini & 4,35 & sangat baik \\
\hline 2. & Memiliki keluarga baru di dalam organisasi ini & 4,46 & sangat baik \\
\hline 3. & Merasa bangga menjadi bagian organisasi & 4,24 & sangat baik \\
\hline 4. & Merasa masalah yang terjadi di organisasi menjadi permasalahan saya juga & 4,28 & sangat baik \\
\hline 5. & Berkeinginan menghabiskan sepanjang hidup di organisasi ini & 4,33 & sangat baik \\
\hline 6. & Memiliki rasa suka duka terhadap organisasi ini & 4,24 & sangat baik \\
\hline 7. & Berkeingin tetap tinggal karena kebutuhan gaji & 4,27 & sangat baik \\
\hline 8. & Berkeingin tetap tinggal karena keuntungan yang didapat & 4,29 & sangat baik \\
\hline 9. & Sangat sulit mendapatkan pekerjaan jika saya keluar & 4,25 & sangat baik \\
\hline 10. & Merasa berat jika meninggalkan organisasi meskipun sangat ingin sekali & 4,29 & sangat baik \\
\hline 11. & Sadar bahwa komitmen adalah hal yang harus saya lakukan & 4,37 & sangat baik \\
\hline 12. & Masih ada tanggungjawab jika saya ingin keluar & 4,43 & sangat baik \\
\hline 13. & Berkeingin menghabisakan sisa karir saya di organisasi ini & 4,45 & sangat baik \\
\hline 14. & Yakin terhadap organisasi ini & 4,40 & sangat baik \\
\hline & Rata-rata variabel komitmen organisasional & 4,33 & sangat baik \\
\hline
\end{tabular}

Berdasarkan hasil deskriptif pada variabel komitmen organisasional, menunjukkan rata-rata variabel ini yaitu 4,33 yang masuk dalam kategori sangat baik. Hal ini menunjukkan secara umum karyawan PT. Arief Nirwana Utama memiliki komitmen yang kuat untuk berkarir pada perusahaan ini. Seluruh item pada variabel ini memiliki rerata yang cukup tinggi sehingga masuk dalam kategori sangat tinggi. Dapat diartikan bahwa karyawan merasa nyaman bekerja pada perusahaan ini.

Tabel 3.

Deskriptif Variabel Disiplin Kerja

\begin{tabular}{|c|l|c|c|}
\hline No. & \multicolumn{1}{|c|}{ Item } & Rerata & Kategori \\
\hline 1. & Saya selalu menaati jam masuk kerja & 4,23 & sangat baik \\
\hline 2. & Saya selalu menaati jam istirahat & 4,23 & sangat baik \\
\hline 3. & Saya selalu menaati jam pulang kerja & 4,23 & sangat baik \\
\hline 4. & Saya selalu berpakaian sesuai yang ditetapkanperusahaan & 4,27 & sangat baik \\
\hline
\end{tabular}




\begin{tabular}{|c|l|c|c|}
\hline No. & \multicolumn{1}{|c|}{ Item } & Rerata & Kategori \\
\hline 5. & Saya selalu bersikap dan bertingkah laku sopan dalam pekerjaan & 4,15 & baik \\
\hline 6. & Saya selalu mematuhi aturan dalam melaksanakan tugas & 4,15 & baik \\
\hline 7. & Saya selalu bertanggugjawab terhadap tugas yang diberikan & 4,27 & sangat baik \\
\hline 8. & Saya melakukan pekerjaan sesuai dengan jabatan yang diemban & 4,20 & sangat baik \\
\hline 9. & Saya menjalin hubungan baik dengan setiap unit kerja di dalam perusahaan & 4,12 & baik \\
\hline 10. & Saya selalu bertingkah laku sesuai dengan norma yang berlaku di perusahaan & 4,21 & sangat baik \\
\hline 11. & Saya selalu menjaga nama baik dan menjunjung visi dan misi perusahaan & 4,47 & sangat baik \\
\hline & Rata-rata variabel disiplin kerja & 4,23 & sangat baik \\
\hline
\end{tabular}

Perhitungan hasil deskriptif pada variabel disiplin kerja menunjukkan rata-rata 4,23 dan nilai ini masuk dalam kategori sangat baik. Berdasarkan nilai rata-rata tersebut dapat diartikan bahwa karyawan PT. Arief Nirwana Utama memiliki disiplin yang baik. Pada ketataan pada waktu menunjukkan rata-rata sebesar 4,23 yang masuk dalam kategori sangat baik. Sehingga, dapat dikatakan bahwa karyawan taat pada jam masuk, istirahat, dan pulang kerja. Pada indikator taat pada peraturan perusahaan, menunjukkan bahwa karyawan patuh pada peraturan. Karyawan selalu berpakian sesuai dengan yang ditetapkan perusahaan, hingga selalu mematuhi aturan dalam melaksanakan tugas. Pada indikator taat terhadap peraturan perilaku dalam pekerjaan menunjukkan bahwa karyawan memiliki perilaku yang baik pula. Hal ini ditandai dengan rata-rata pada item ke 7,8, dan 9 yang memiliki kategori baik, dan sangat baik. Pada indikator taat pada peraturan lainnya menunjukkan bahwa karyawan memiliki kepatuhan yang baik yang ditandai dengan rerata item ke 10 dan 11 yang masuk dalam kategori sangat baik.

\section{Tabel 4.}

\section{Deskriptif Variabel Kepuasan Kerja}

\begin{tabular}{|c|l|c|c|}
\hline No. & \multicolumn{1}{|c|}{ Item } & Rerata & Kategori \\
\hline 1. & Pekerjaan rutin yang saya lakukan memerlukan kemampuan & 4,36 & Sangat baik \\
\hline 2. & Pekerjaan tidak rutin yang saya lakukan mempunyai jenis yang beragam & 4,23 & Sangat baik \\
\hline 3. & Saya bebas melaksanakan pekerjaan dengan cara saya & 4,24 & Sangat baik \\
\hline 4. & Atasan memberikan penghargaan terhadap keberhasilan saya & 4,25 & Sangat baik \\
\hline 5. & Pembayaran gaji saya terima secara adil & 4,25 & Sangat baik \\
\hline 6. & Pembayaran gaji saya terima sesuai dengan harapan & 4,27 & Sangat baik \\
\hline 7. & Kebijakan promosi dilakukan secara adil & 4,34 & Sangat baik \\
\hline 8. & Kebijakan promosi sesuai dengan harapan saya & 4,25 & Sangat baik \\
\hline 9. & Lingkungan kerja saya nyaman & 4,31 & Sangat baik \\
\hline 10. & Lingkungan kerja saya bersih & 4,15 & Baik \\
\hline
\end{tabular}




\begin{tabular}{|c|l|c|c|}
\hline 11. & Lingkungan kerja saya tertata rapi & 4,16 & Baik \\
\hline 12. & Lingkungan kerja saya tidak bising & 4,27 & Sangat baik \\
\hline 13. & Lingkungan kerja saya mempunyai fasilitas internet & 4,27 & Sangat baik \\
\hline 14. & Lingkungan kerja memudahkan saya menyelesaikan pekerjaan & 4,24 & Sangat baik \\
\hline 15. & Sikap toleran dari rekan kerja & 4,36 & Sangat baik \\
\hline 16. & Atasan bersikap ramah terhadap saya & 4,23 & Sangat baik \\
\hline 17. & Atasan mendengarkan keluhan saya & 4,24 & Sangat baik \\
\hline 18. & Atasan mendengarkan saran saya & 4,25 & Sangat baik \\
\hline 19. & Atasan memberikan hadiah atas keberhasilan saya & 4,25 & Sangat baik \\
\hline 20. & Atasan memberikan pujian atas keberhasilan saya & 4,27 & Sangat baik \\
\hline 21. & Atasan memberikan motivasi kepada saya & 4,34 & Sangat baik \\
\hline & Rata-rata variabel kepuasan kerja & 4,26 & Sangat baik \\
\hline
\end{tabular}

Rata-rata variabel kepuasan kerja yaitu 4,26 yang masuk dalam kategori sangat baik. Dapat dikatakan bahwa karyawan PT. Arief Nirwana Utama memiliki kepuasan atas pekerjaannya. Mayoritas item pada variabel ini masuk dalam kategori sangat baik. Masing-masing indikator pada variabel kepuasan kerja dikatakan baik bahkan sangat baik yaitu kerja yang menantang, penghargaan yang sesuai, kondisi kerja yang mendukung, dan kolega yang suportif.

\section{Analisis Kuantitatif}

Tabel 5.

Pengaruh Langsung Dan Pengaruh Tidak Langsung

\begin{tabular}{|c|c|c|c|}
\hline Pengaruh variable & Langsung & Tidak langsung (melalui Z) & Total \\
\hline $\mathrm{X}_{1} \rightarrow \mathrm{Z}$ & 0,641 & 0 & 0,641 \\
\hline $\mathrm{X}_{2} \rightarrow \mathrm{Z}$ & 0,380 & 0 & 0,380 \\
\hline $\mathrm{X}_{1} \rightarrow \mathrm{Y}$ & 0,348 & 0,430 & 0,778 \\
\hline $\mathrm{X}_{2} \rightarrow \mathrm{Y}$ & 0,614 & 0,255 & 0,869 \\
\hline $\mathrm{Z} \rightarrow \mathrm{Y}$ & 0,671 & 0 & 0,671 \\
\hline
\end{tabular}

\section{Pengujian pengaruh tidak langsung variabel komitmen organisasional (X1) terhadap kinerja (Y) melalui kepuasan kerja (Z)}

Berdasarkan hasil olah data diperoleh koefisien regresi komitmen organisasional (X1) langsung sebesar 0,348. Koefisien regresi pengaruh tidak langsungnya yaitu 0,641 x 0,671=0,430. Koefisien komitmen organisasional (X1) tidak langsung lebih besar dari koefisien komitmen 
organisasional (X1) langsung. Variabel intervening yaitu kepuasan kerja memberikan pengaruh sebesar 0,671 terhadap kinerja pada variabel komitmen organisasional (X1).

\section{Pengujian pengaruh tidak langsung variabel disiplin kerja (X2) terhadap kinerja (Y) melalui melalui kepuasan kerja (Z)}

Berdasarkan hasil olah data diperoleh koefisien regresi disiplin kerja (X2) langsung sebesar 0,614 koefisien regresi pengaruh tidak langsungnya yaitu $0,380 \mathrm{x} 0,671=0,255$. Koefisien disiplin kerja (X2) tidak langsung lebih kecil dari koefisien disiplin kerja (X2) langsung. Variabel intervening yaitu komitmen memberikan pengaruh sebesar 0,671 terhadap kinerja variabel disiplin kerja (X2).

Tabel 6.

Rekapitulasi Hasil Uji Hipotesis

\begin{tabular}{|c|c|c|}
\hline Hipotesis & Hipotesis & Keterangan \\
\hline H1 & $\begin{array}{l}\text { Diduga terdapat pengaruh komitmen organisasional terhadap } \\
\text { kepuasan kerja di PT Arief Nirwana Utama }\end{array}$ & Terbukti \\
\hline $\mathrm{H} 2$ & $\begin{array}{l}\text { Diduga terdapat pengaruh disiplin kerja terhadap kepuasan kerja di } \\
\text { PT Arief Nirwana Utama }\end{array}$ & Terbukti \\
\hline H3 & $\begin{array}{l}\text { Diduga terdapat pengaruh komitmen organisasional dan disiplin } \\
\text { terhadap kepuasan kerja di PT Arief Nirwana Utama }\end{array}$ & Terbukti \\
\hline $\mathrm{H} 4$ & $\begin{array}{l}\text { Diduga terdapat pengaruh komitmen organisasional terhadap kinerja } \\
\text { karyawan di PT Arief Nirwana Utama }\end{array}$ & Terbukti \\
\hline H5 & $\begin{array}{l}\text { Diduga terdapat pengaruh disiplin kerja terhadap kinerja karyawan di } \\
\text { PT Arief Nirwana Utama }\end{array}$ & Terbukti \\
\hline H6 & $\begin{array}{l}\text { Diduga terdapat pengaruh komitmen organisasional dan disiplin } \\
\text { terhadap kinerja karyawan di PT Arief Nirwana Utama }\end{array}$ & Terbukti \\
\hline $\mathrm{H} 7$ & $\begin{array}{l}\text { Diduga terdapat pengaruh kepuasan kerja terhadap kinerja karyawan } \\
\text { di PT Arief Nirwana Utama }\end{array}$ & Terbukti \\
\hline $\mathrm{H} 8$ & $\begin{array}{l}\text { Diduga ada pengaruh secara tidak langsung komitmen organisasional } \\
\text { terhadap kinerja karyawan daripada pengaruh secara langsung } \\
\text { komitmen organisasional terhadap kinerja karyawan melalui } \\
\text { kepuasan kerja }\end{array}$ & Terbukti \\
\hline H9 & $\begin{array}{l}\text { Diduga ada pengaruh secara tidak langsung disiplin kerja terhadap } \\
\text { kinerja daripada pengaruh secara langsung disiplin kerja terhadap } \\
\text { kinerja karyawan melalui kepuasan kerja }\end{array}$ & Terbukti \\
\hline
\end{tabular}

\section{PEMBAHASAN}

\section{Pengaruh komitmen organisasional (X1) terhadap kepuasan kerja (Z)}

Terdapat pengaruh yang signifikan komitmen organisasional terhadap kepuasan kerja, diterima. Hal ini dibuktikan dengan nilai signifikansi hasil regresi variabel komitmen organisasional terhadap kepuasan kerja yaitu sebesar 0,000 . Koefisien pada variabel ini yaitu sebesar 0,728 yang dapat diartikan adanya pengaruh positif dari variabel komitmen terhadap kepuasan kerja. Nilai tersebut juga dapat diartikan setiap kenaikan satu-satuan dari variabel ini, akan meningkatkan kepuasan kerja sebesar 0,728 . 
Hasil penelitian ini sejalan dengan penelitian yang telah dilakukan Chandra (2013) dalam penelitian "Pengaruh Komitmen Organisasi dan Kepemimpinan terhadap Kepuasan Kerja dan Kinerja Karyawan PD. Wonoagung Sejahtera di Gresik". Hasil penelitian tersebut menunjukan bahwa komitmen organisasi berpengaruh terhadap kepuasan kerja.

Komitmen organisasional mempunyai peran peting dalam meningkatkan kepuasan kerja. Agar harapan kerja terpenuhi komitmen organisasional harus dapat diterapkan dengan baik yang nantinya akan menimbulkan kepuasan kerja dalam organsiasi. Badjuri (dalam Arifah dan Romadhon 2015) yang menyatakan bahwa komitmen organisasional mempengaruhi berbagai perilaku penting agar organisasi dapat tumbuh mana kala harapan kerja terpenuhi oleh organisasi dengan baik. Selanjutnya dengan terpenuhinya harapan kerja ini akan menimbulkan kepuasan kerja. Hubungan dari kepuasan kerja dengan turnover interntion dan komitmen organisasi lebih dipengaruhi oleh kepuasan kerja sebagai antecedent dari komitmen organisasional (Lin and Ma, 2004; Tett and Meyer, 1993; dalam Iqbal et al 2014).

Seorang karyawan yang memiliki komitmen yang kuat untuk tetap bekerja di perusahaan PT.Arief Nirwana Utama seperti karyawan yang merasakan kenyaman dengan bekerja di perusahaan tersebut tentunya akan memiliki kepuasan dengan bekerja di perusahaan PT.Arief Nirwana Utama. Karyawan yang berkeinginan menghabiskan sisa karirnya pada perusahaan PT.Arief Nirwana Utama akan memberikan kepuasan tersendiri pada karyawan.

\section{Pengaruh disiplin kerja (X2) terhadap kepuasan kerja (Z)}

Terdapat pengaruh yang signifikan disiplin kerja terhadap kepuasan kerja, diterima. Hal ini dibuktikan dengan nilai signifikansi hasil regresi variabel disiplin kerja terhadap kepuasan kerja yaitu sebesar 0,000. Koefisien pada variabel ini yaitu sebesar 0,398 yang dapat diartikan adanya pengaruh positif dari variabel disiplin kerja terhadap kepuasan kerja. Nilai tersebut juga dapat diartikan setiap kenaikan satu-satuan dari variabel ini, akan meningkatkan kepuasan kerja sebesar 0,398 .

Penelitian ini sejalan dengan penelitian yang telah dilakukan oleh Sudiyanto (2015) dalam penelitian "Pengaruh Disiplin, Budaya Kerja, dan Motivasi terhadap Kepuasan Kerja pegawai pada Fakultas Ekonomi Universitas PGRI Palembang”. Hasil penelitian tersebut menunjukan bahwa disiplin kerja berpengaruh secara positif dan signifikan terhadap kepuasan kerja.

Kedisiplinan merupakan fungsi operasional manajemen sumber daya manusia yang terpenting karena semakin baik disiplin kerja pegawai, semakin baik kinerja yang dapat dicapai. Tanpa disiplin yang baik, sulit bagi organisasi untuk mencapai hasil yang optimal. Kedisiplinan merupakan faktor yang utama yang diperlukan sebagai alat peringatan terhadap pegawai yang tidak mau berubah sifat dan perilakunya.

Karyawan yang memiliki kedisiplinan dalam bekerja seperti karyawan yang menaati jam masuk dan pulang kerja akan mempengaruhi bagi karyawan tersebut dalam bekerja. Selain itu karyawan yang selalu bekerja dengan menjaga tingkah laku sesuai dengan norma yang berlaku dan melakukan pekerjaan sesuai dengan jabatan atau tanggungjawab, akan memberikan kepuasan karyawan dalam bekerja.

\section{Pengaruh komitmen organisasional (X1) dan disiplin kerja (X2) secara simultan terhadap kepuasan kerja $(\mathrm{Z})$}

Terdapat pengaruh yang signifikan komitmen organisasional dan disiplin kerja terdahap kepuasan kerja secara simultan, diterima. Hal ini dibuktikan dengan nilai signifikansi hasil regresi variabel disiplin kerja dan komitmen organisasional terhadap kepuasan kerja yaitu sebesar 0,000. Hasil koefisien determinasi yaitu 0,683 sehingga dapat diartikan variabel komitmen organisasional dan disiplin kerja mempengaruhi kepuasan kerja sebesar 68,3\%. Dapat diartikan bahwa terdapat pengaruh yang cukup tinggi variabel komitmen organisasional dan disiplin kerja terdahap kepuasan kerja.

Kepuasan kerja mencerminkan perasaan seseorang terhadap pekerjaannya. Ini dapat dilihat 
dari sikap yang mereka tunjukan terhadap pekerjaan dan tantangan dalam berbagai kondisi kerja. Untuk mengetahui keadaan emosional seseorang memang tidak dapat kita lihat secara langsung akan tetapi hanya akan mempu untuk kita rasakan, maka dari itu puas atau tidak nya seorang karyawan dapat dilihat dari bagaimana dia dalam berprilaku, mengerjakan pekerjaan dan pola fikir orang tersebut dalam menyelesaikan masalah.

\section{Pengaruh komitmen organisasional (X1) terhadap kinerja (Y)}

Terdapat pengaruh yang signifikan komitmen organisasional terdahap kinerja, diterima. Hal ini dibuktikan dengan nilai signifikansi hasil regresi variabel komitmen organisasional terhadap kinerja karyawan yaitu sebesar 0,000. Koefisien pada variabel ini yaitu sebesar 0,365 yang dapat diartikan adanya pengaruh positif dari variabel komitmen terhadap kinerja. Nilai tersebut juga dapat diartikan setiap kenaikan satu-satuan dari variabel ini, akan meningkatkan kinerja karyawan sebesar 0,365 .

Hasil penelitian ini sejalan dengan penelitian yang telah dilakukan Nydia (2012) dalam penelitian "Pengaruh Komitmen Organisasi Terhadap Kinerja Karyawan Lapangan SPBU COCO Pertamina MT Haryono,". Hasil penelitian tersebut menunjukan bahwa komitmen organisasi yang terdiri dari komitmen afektif, berkelanjutan dan normative berpengaruh secara simultan terhadap kinerja karyawan lapangan SPBU COCO Pertamina MT Haryono. Selain itu, penelitian ini sejalan dengan penelitian Utomo (2011) dalam penelitian "Pengaruh Motivasi Kerja, Kepuasan Kerja, dan Komitmen Organisasional terhadap Kinerja Pegawai” (Studi pada pegawai Setda Kabupaten Pati). Hasil penelitian tersebut menunjukan bahwa komitmen organisasi terbukti secara signifikan memiliki pengaruh positif terhadap kinerja pegawai Sekretariat Daerah Kabupaten Pati.

Komitmen mempunyai peran penting dalam meningkatkan kinerja karyawan dalam sebuah organisasi. Tingginya komitmen akan berimbas pada kinerja karyawan yang semakin meningkat. Pernyataan ini didukung oleh Khan et al (Rautisa dan Rahmawati ,2012) yang mengatakan komitmen dari seorang karyawan terhadap organisasinya dapat menjadi instrumen penting untuk meningkatkan kinerja dari karyawan tersebut. Hal ini diperkuat oleh Smith (Ciptodiharjo, 2013) menunjukkan bahwa komitmen organisasi berhubungan signifikan positif yang terhadap kinerja pegawai produksi.

\section{Pengaruh disiplin kerja (X2) terhadap kinerja (Y)}

Terdapat pengaruh yang signifikan disiplin kerja terdahap kinerja, diterima. Hal ini dibuktikan dengan nilai signifikansi hasil regresi variabel disiplin kerja terhadap kinerja karyawan yaitu sebesar 0,000. Koefisien pada variabel ini yaitu sebesar 0,593 yang dapat diartikan adanya pengaruh positif dari variabel disiplin kerja terhadap kinerja. Nilai tersebut juga dapat diartikan setiap kenaikan satu-satuan dari variabel ini, akan meningkatkan kinerja karyawan sebesar 0,593.

Penelitian ini sejalan dengan penelitian yang telah dilakukan oleh Hidayati (2014) dalam penelitian "Analisis Pengaruh Motivasi dan Disiplin Kerja terhadap Kinerja Karyawan PT. Kemilau Indah Permana Kebakkramat Karanganyar". Hasil penelitian ini menunjukan bahwa disiplin kerja berpengaruh positif dan signifikan terhadap kinerja karyawan PT. Kemilau Indah Permana Kebakkramat Karanganyar.

Kedisiplinan karyawan seperti kedisiplinan karyawan dalam mematuhi aturan dan melaksanakan tugas, akan mempengaruhi bagaimana karyawan tersebut menyelesaikan pekerjaanya dan akan menentukan dan mempengaruhi bagaimana kualitas dari pekerjaannya. Karyawan yang memiliki kedisiplinan yang baik, khususnya pada hal ketepatan waktu tentunya akan menentukan kemampuan karyawan dalam menyelesaikan tugasnya dalam waktu yang telah ditetapkan oleh perusahaan.

Karyawan yang memiliki kedisplinan yang tinggi, juga tercermin bagaimana karyawan bertanggungjawab terhadap pekerjaan yang diberikan oleh pimpinan. Tanggungjawab karyawan tersebut akan menentukan bagaimana karyawan memberikan seluruh kemampuannya untuk menyelesaikan pekerjaannya. Hal ini tentunya akan memberikan hasil kerja karyawan yang lebih 
baik.

\section{Pengaruh komitmen organisasional (X1) dan disiplin kerja (X2) secara simultan terhadap kinerja (Y)}

Terdapat pengaruh yang signifikan komitmen organisasional dan disiplin kerja terdahap kinerja secara simultan, diterima. Hal ini dibuktikan dengan nilai signifikansi hasil regresi variabel disiplin kerja dan komitmen organisasional terhadap kinerja yaitu sebesar 0,000. Hasil koefisien determinasi yaitu 0,609 sehingga dapat diartikan variabel komitmen organisasional dan disiplin kerja mempengaruhi kinerja karyawan sebesar 60,9\%. Dapat diartikan bahwa terdapat pengaruh yang cukup tinggi variabel komitmen organisasional dan disiplin kerja terdahap kinerja karyawan.

Kinerja adalah sesuatu yang penting bagi instansi, khususnya kinerja pegawai yang bisa membawa perusahaan pada pencapaian tujuan yang diharapkan. Baik atau buruknya kinerja pegawai dapat berpengaruh pada baik buruknya kinerja instansi. Kinerja bisa mempengaruhi berlangsungnya kegiatan suatu organisasi perusahaan, semakin baik kinerja yang ditunjukan oleh para pegawai akan sangat membantu dalam perkembangan organisasi atau perusahaan tersebut.

Karyawan yang memiliki komitmen organisasional dan disiplin kerja akan mempengaruhi kinerja karyawan. Karyawan yang memiliki komitmen yang tinggi pada perusahaan dan memiliki kedisiplinan yang tinggi akan meningkatkan kinerja karyawan atau dengan kata lain karyawan akan menghasilkan kinerja yang lebih baik. Karyawan yang merasa nyaman dan bangga dengan bekerja di perusahaan PT.Arief Nirwana Utama dan karyawan yang mematuhi peraturan dalam melaksanakan tugasnya tentunya akan memberikan rasa nyaman karyawan dalam bekerja dan akan menghasilkan kinerja yang lebih baik.

\section{Pengaruh kepuasan kerja $(\mathrm{Z})$ terhadap kinerja $(Y)$}

Terdapat pengaruh yang signifikan kepuasan kerja terdahap kinerja, diterima. Hal ini dibuktikan dengan nilai signifikansi hasil regresi variabel kepuasan kerja terhadap kinerja karyawan yaitu sebesar 0,000. Koefisien pada variabel ini yaitu sebesar 0,619 yang dapat diartikan adanya pengaruh positif dari variabel disiplin kerja terhadap kinerja. Nilai tersebut juga dapat diartikan setiap kenaikan satu-satuan dari variabel ini, akan meningkatkan kinerja karyawan sebesar 0,619. Hasil koefisien determinasi yaitu 0,450 sehingga dapat diartikan variabel kepuasan kerja mempengaruhi kinerja karyawan sebesar $45,0 \%$.

Hasil penelitian ini dejalan dengan penelitian yang dilakukan oleh Jayanti (2014) dalam "Analisis Pengaruh Motivasi Kerja, Kepuasan Kerja, Kontrak Psikologis, Disiplin Kerja dan Lingkungan Kerja terhadap Kinerja Karyawan RSUD Kota Semarang”. Hasil penelitian ini menunjukan bahwa kepuasan kerja memiliki pengaruh positif dan signifikan terhadap kinerja karyawan.

Keberhasilan organisasi dipengaruhi oleh adanya tingkat kepuasan yang dirasakan karyawan. Kepuasan yang dirasakan setiap karyawan akan mengakibatkan peningkatan dalam kinerja seorang karyawan, karena menganggap pekerjaannya sebagai sebagai suatu yang menyenangkan. Pernyataan ini didukung oleh Robbins (Indrawati, 2013) dan Tjahjono \& Rinairti (2015) mengenai dampak kepuasan kerja terhadap kinerja karyawan, yang menyatakan bahwa karyawan yang puas berkemungkinan lebih besar untuk berbicara secara positif tentang organisasi, membantu yang lain, dan berbuat kinerja pekerjaan mereka melampaui perkiraan normal.

\section{Pengaruh tidak langsung komitmen organisasional (X1) terhadap kinerja (Y) melalui kepuasan kerja $(Z)$}

Terdapat pengaruh secara tidak langsung variabel komitmen organisasional (X1) terhadap kinerja (Y) melalui kepuasan kerja (Z). Koefisien pengaruh tidak langsung tersebut yaitu sebesar 0,430 , sedangkan besarnya pengaruh langsung yaitu sebesar 0,348. Dapat ketahui bahwa pengaruh komitmen organisasional terhadap kinerja lebih besar secara tidak langsung atau dimediasi oleh kepuasan kerja. 
Menurut Luthans (Kristianto, et al 2013) kepuasan kerja dihasilkan dari persepsi karyawan mengenai seberapa baik pekerjaan mereka menyediakan hal yang dipandang penting. Variabel kepuasan kerja dapat menjadi variabel intervening antara pengaruh komitmen organisasional terhadap kinerja karyawan. Karyawan yang memiliki komitmen organisasional yang tinggi namun memiliki kepuasan kerja yang rendah akan menurunkan kinerja karyawan. Namun, jika karyawan memiliki komitmen organisasional yang tinggi dan memiliki kepuasan kerja yang tinggi tentunya juga akan meningkatkan kinerja karyawan.

Seorang karyawan yang memiliki komitmen yang kuat untuk mengahabiskan masa atau sisa karirnya di perusahaan PT.Arief Nirwana Utama menunjukkan adanya komitmen yang kuat pada diri karyawan tersebut. Namun, disisi lain karyawan tersebut merasa bahwa penerimaan gaji setiap bulannya tidak sesuai dengan apa yang telah karyawan berikan kepada perusahaan. Hal ini menunjukkan adanya komitmen karyawan yang tinggi namun pada memiliki kepuasan kerja yang rendah. Dalam hal ini, kepuasan kerja yang rendah tersebut dapat menyebabkan kinerja karyawan yang juga akan menurun.

Dalam contoh kasus lain misalnya, karyawan yang memiliki rasa bangga dengan menjadi bagian pada perusahaan PT.Arief Nirwana Utama menunjukkan adanya komitmen yang tinggi pada karyawan tersebut. Saat yang bersamaan, karyawan mendapatkan penghargaan terhadap keberhasilannya. Dalam hal ini, karyawan memiliki kepuasan kerja yang tinggi. Kepuasan kerja ini secara tidak langsung memberikan pengaruh pada kinerja karyawan. Adanya komitmen yang tinggi dan kepuasan kerja karyawan yang juga tinggi akan meningkatkan kinerja karyawan.

\section{Pengaruh tidak langsung disiplin kerja (X2) terhadap kinerja (Y) melalui kepuasan kerja} (Z)

Terdapat pengaruh secara tidak langsung variabel disiplin kerja terhadap kinerja melalui kepuasan kerja. Koefisien pengaruh tidak langsung tersebut yaitu sebesar 0,255, sedangkan besarnya pengaruh langsung yaitu sebesar 0,614. Dapat ketahui bahwa pengaruh disiplin kerja terhadap kinerja lebih besar secara langsung atau tanpa dimediasi oleh kepuasan kerja, namun secara statistik juga diperoleh terdapat pengaruh secara tidak langsung disiplin kerja terhadap kinerja.

Kinerja adalah hasil kerja yang dihasilkan oleh kemampuan dari individu atau kelompok yang dilakukan berdasarkan kecakapan, pengalaman, kesungguhan dan waktu dengan maksimal. Menurut Mangkunegara (2011) kinerja adalah hasil kerja secara kualitas dan kuantitas yang dicapai oleh seorang pegawai dalam melaksanakan tugasnya sesuai dengan tanggung jawab yang diberikan kepadanya.

Variabel kepuasan kerja dapat menjadi variabel intervening antara pengaruh disiplin kerja terhadap kinerja karyawan. Karyawan yang memiliki kinerja yang tinggi namun memiliki kepuasan kerja yang rendah akan menurunkan kinerja karyawan. Namun, jika karyawan memiliki disiplin kerja yang tinggi dan memiliki kepuasan kerja yang tinggi tentunya juga akan meningkatkan kinerja karyawan.

Disiplin kerja harus dapat diterapkan dalam organisasi dan harus dilaksanakan oleh setiap karyawan, dengan adanya disiplin kerja, maka diharapkan kinerja meningkat.Pernyataan ini didukung oleh Hasibuan (Ardansyah, 2014) yang menyatakan bahwa kedisiplinan kerja diartikan bilaman karyawan selalu datang dan pulang tepat waktu, mengerjakan semua pekerjaan dengan baik, mematuhi semua peraturan perusahaan dan norma-norma sosial yang berlaku. Keberhasilan organisasi dipengaruhi oleh adanya tingkat kepuasan yang dirasakan karyawan. Kepuasan yang dirasakan setiap karyawan akan mengakibatkan peningkatan dalam kinerja seorang karyawan, karena menganggap pekerjaannya sebagai sebagai suatu yang menyenangkan. 


\section{KESIMPULAN}

Berdasarkan hasil penelitian yang telah dilakukan di PT. Arief Nirwana Utama dapat diberikan beberapa kesimpulan sebagai berikut :

a. Terdapat pengaruh yang signifikan komitmen organisasional terhadap kepuasan kerja karyawan

b. Terdapat pengaruh yang signifikan disiplin kerja terhadap kepuasan kerja karyawan

c. Terdapat pengaruh yang signifikan komitmen organisasional dan disiplin kerja secara simultan terhadap kepuasan kerja karyawan

d. Terdapat pengaruh yang signifikan komitmen organisasional terhadap kinerja karyawan

e. Terdapat pengaruh yang signifikan disiplin kerja terhadap kinerja karyawan

f. Terdapat pengaruh yang signifikan komitmen organisasional dan disiplin kerja secara simultan terhadap kinerja karyawan

g. Terdapat pengaruh yang signifikan kepuasan kerja terhadap kinerja karyawan

h. Terdapat pengaruh tidak langsung yang signifikan komitmen organisasional terhadap kinerja melalui kepuasan kerja karyawan

i. Terdapat pengaruh tidak langsung yang signifikan disiplin kerja terhadap kinerja melalui kepuasan kerja karyawan

\section{SARAN}

Berdasarkan hasil penelitian yang telah dilakukan di PT. Arief Nirwana Utama dapat diberikan beberapa saran sebagai berikut :

a. Bagi Pimpinan PT. Arief Nirwana Utama

Dalam penelitian ini menunjukkan bahwa kepuasan kerja berpengaruh signifikan terhadap kinerja karyawan. Variabel ini juga dapat berperan sebagai variabel intervening dalam mempengaruhi kinerja karyawan. Indikator-indikator kepuasan kerja salah satunya adalah bagaimana pimpinan atau atasan bersikap pada karyawan, diantaranya keramahan, mendengarkan saran, memberikan penghargaan, dan mampu memberikan motivasi pada karyawan. Oleh karena itu, pimpinan dapat lebih meningkatkan perhatiannya pada karyawan untuk dapat meningkatkan kinerja karyawan.

b. Bagi Peneliti Selanjutnya

Dalam penelitian dianalisis bagaimana pengaruh komitmen organisasional dan disiplin kerja terhadap kinerja karyawan. Kedua variabel independen tersebut merupakan faktor internal karyawan. Bagi peneliti selanjutnya, dapat menganalisis faktor internal yang lebih mendalam seperti bagaimana motivasi kerja karyawan, budaya organisasi, bagimana kepemimpinan pimpinan karyawan.

\section{DAFTAR PUSTAKA}

Ardansyah \& Wasilawati., 2014, Pengawasan, Disiplin Kerja, dan Kinerja Pegawasi Badan Pusat Statistik Kabupaten Lampung Tengah, Jurnal Manajemen dan Kewirausahaan, 16(2).

Agusta., I.M.T.F., dan Supartha., W.G., 2013, Pengaruh Kepemimpinan, Hubungan Kerja terhadap Kepuasan Kerja Karyawan Pada PT. Bintang Bali Indah Denpasar.

Arifah, D.A., dan Romadhon, C., 2015, Pengaruh Komitmen Organisasi, Komitmen Profesional dan Gaya Kepimpinan terhadap Kepuasan Kerja dengan Motivasi sebagai Variabel Interverning, Conference in Business, Accounting, and Management, 2(1). 
Arina, Y., 2015, Pengaruh Lingkungan Kerja dan Disiplin Kerja terhadap Kepuasan Kerja Karyawan Pada CV. Yamaha Siteba Padang.

Baihaqi, M.I., 2013, Pengaruh Kepemimpinan dan Disiplin Kerja terhadap Kinerja Pegawai dengan Kepuasan Kerja sebagai Variabel Moderating. Naskah Publikasi.

Chandra, A.E., 2013, Pengaruh Komitmen Organisasi dan Kepemimpinan terhadap Kepuasan Kerja dan Kinerja Karyawan PD. Wonoagung Sejahtera di Gresik, Thesis Program Magister Manajemen, Surabaya, Universita Katolik Widya Mandala Surabaya.

Ciptodihardjo, I., 2013, Pengaruh Kepemimpinan, Motivasi, Kepuasan Kerja terhadap Komitmen Organisasional dan Kinerja Karyawan pada Karyawan PT. Smartfren, Tbk di Surabaya, Jurnal Universitas Katolik Widya Mandala Surabaya, 2(1)

Gomes, F.C., 2003, Manajemen Sumber Daya Manusia. Yogyakarta: Andi.

Hidayati, 2014, Analisis Pengaruh Motivasi dan Disiplin Kerja terhadap Kinerja Karyawan PT. Kemilau Indah Permana Kebakkramat Karanganyar, Naskah Publikasi.

Indrawati, A.D., 2013, Pengaruh Kepuasan Kerja terhadap Kinerja dan Kepuasan Pelanggan Pada Rumah Sakit Swasta di Kota Denpasar, Jurnal Manajemen, Strategi Bisnis, dan Kewirausahaan, 7(2).

Iqbal, S. et al., 2014, The Impact of Organizational Commitment, Job Satisfaction, Job Stress and Leadership Support on Turnover Intention in Educational Institutes, International Journal of Human Resource Studies, 4(2).

Istijanto, 2010, Riset Sumber Daya Manusia. Jakarta : PT. Gramedia Pustaka Utama.

Jayanti, S., 2014, Analisis Pengaruh Motivasi Kerja, Kepuasan Kerja, Kontrak Psikologi, Disiplin Kerja, dan Lingkungan Kerja terhadap Kinerja Karyawan RSUD Kota Semarang.

Kristianto, D. et al., 2011, Pengaruh Kepuasan Kerja terhadap Kinerja Karyawan dengan Komitmen Organisasional sebagai Variabel Intervening (Studi pada RSUD Tugurejo Semarang).

Mangkunegara, A.A, Anwar Prabu, 2011, Manajemen Sumber Daya Manusia Perusahaan. Remaja Rosdakarya, Bandung.

Nanda, L., 2014, Analisis Pengaruh Motivasi Kerja, Pengendalian Internal, dan Komitmen Organisasi terhadap Kinerja Karyawan (Studi Empiris Pada AJB Bumi Putera 1912 Kantor Cabang Solo Gladag), Naskah Publikasi.

Nelly, T.F., 2013, Pengaruh Komitmen dan Motivasi terhadap Kinerja pada Karyawan Kadin DKI Jakarta, EconoSains, 11 (2), Agustus.

Nydia, Y.T., 2012, Pengaruh Komitmen Organisasional terhadap Kinerja Karyawan Lapangan SPBU Coco Pertamina MT Haryono, Skripsi Jurusan Ilmu Administrasi Fakultas Ilmu Sosial dan Ilmu Politik, Depok, Universitas Indonesia.

Putri, P.Y.A., dan Latrini, M.Y., 2013, Pengaruh Kepuasan Kerja terhadap Kinerja Karyawan Sektor Publik dengan In-Role Performance dan Innovative Performance sebagai Variabel Mediasi, E-Jurnal Akuntansi Universitas Udayana, 5(3).

Rivai, V., 2011, Manajemen Sumber Daya Manusia Untuk Perusahaan Dari Teori Ke Praktek. PT. Rajagrafindo Persada, Jakarta.

Robbins, S., 2002, Perilaku Organisasi. Jakarta: Erlangga.

Sopiah, 2008, Perilaku Organisasi, Yogyakarta, C.V ANDI OFFSET.

Sudiyanto, T., 2015, Pengaruh Disiplin, Budaya Kerja, dan Motivasi terhadap Kepuasan Kerja Pegawai Pada Fakultas Ekonomi Universitas PGRI Palembang, Jurnal Media Wahana 
Ekonomika, 12(1).

Sumarsono, S., 2004, Metode Riset Sumber Daya Manusia.Yogyakarta : Graha Ilmu.

Sutrisno, E., 2010, Manajemen Sumber Daya Manusia. Cetakan Ketiga, Kencana Prenada Media Group, Jakarta.

Taurisa, C.M., dan Ratnawati, I., 2012, Pengaruh Budaya Organisasi dan Kepuasan Kerja terhadap Komitmen Organisasional dalam Meningkatkan Kinerja Karyawan (Studi pada PT, Sido Muncul Kaligawe Semarang), Jurnal Bisnis dan Ekonomi, 19(2).

Tjahjono, H.K. \& Riniarti. 2015. Evaluasi keadilan praktik tunjangan kinerja pada kepuasan dan kinerja karyawan di kantor BPS DIY. Jurnal Siasat Bisnis. 19(2):124-131.

Tjahjono, H,K, Palupi, M. \& Dirgahayu, P.G. 2015. Peran pemediasian kepuasan karir pada pengaruh keadilan distributif dan keadilan prosedural karir pada komitmen afektif karyawan swasta di provinsi daerah istimewa yogyakarta. Jurnal Akuntansi dan Manajemen (Akmenika). 12(1):563-573.

Umar, A., 2011, Pengaruh Upah, Motivasi Kerja, dan Kepuasan Kerja terhadap Kinerja Pekerja pada Industri Manufaktur di Kota Makassar, Jurnal Aplikasi Manajemen, 10(2).

Utomo, J., dan Suwardi, 2011, Pengaruh Motivasi Kerja, Kepuasan Kerja, dan Komitmen Organisasional terhadap Kinerja Pegawai (Studi Pada Pegawai Setda Kabupaten Pati), Analisis Manajemen, 5(1). 